\title{
Clive Barker
}

\section{$1931-2005$}

It is with deep regret that we record the death following a stroke of our friend and colleague Clive Barker on 17 March 2005.

Clive had been co-editor of New Theatre Quarterly since its first appearance in 1985, and during a multi-faceted career had been an actor with Joan Littlewood's Theatre Workshop during its vintage years, a member of the Drama Departments at the Universities of Birmingham and Warwick, and an actor trainer whose Theatre Games was a seminal work.

Clive had made an excellent recovery following an earlier stroke three years ago, and was running a series of workshops for actors with learning disabilities at the Theatre Royal, York, in the week of his death. He died, as he would have wished, in harness and in the company of friends.

His death occurred just as this issue was due to go to press, and we shall of course pay fuller tribute to his life and work in a later issue. We invite his many friends and colleagues to send us their thoughts and recollections.

SIMON TRUSSLER

MARIA SHEVTSOVA 